\title{
THE CHAETOTAXY OF CYPRIDACEA (CRUSTACEA, OSTRACODA) LIMBS: PROPOSALS FOR A DESCRIPTIVE MODEL
}

\author{
by \\ NICO W. BROODBAKKER \\ Institute of Taxonomic Zoology, University of Amsterdam, \\ P.O. Box 20125, 1000 HC Amsterdam, The Netherlands
}

$\&$

DAN L. DANIELOPOL

Limnological Institute, Austrian Academy of Sciences, Gaisberg 116, A-5310 Mondsee, Austria

\begin{abstract}
The need for better and more systematic descriptions of the chaetotaxy (especially data concerning the shape, structure and pattern of distribution of the setae) is emphasized. The historical developments of studies in chaetotaxy are reviewed.

Two basic types of cuticular processes can be recognized: setae and pseudochaetae. The former have sensorial and mechanical functions, the latter only a mechanical function. A special type of seta is the aesthetasc or the chemosensorial receptor. Using the shape and structure of the setae, most of them can be classified in the following categories: simple, plumed, serrate and chelate.

The importance of developmental studies for the establishment of homologies in chaetotaxy is stressed.

Examples of functional morphology of setae are discussed. It is emphasized that the functional morphology of most of the setae can be better understood when the whole organ is studied of which the setae are only a component. Not all the setae have an adaptive significance.

A descriptive model of the chaetotaxy of cypridacean ostracods is presented. The different characteristics of the setae as well as their position on the limbs are coded by letters and numerals using simple formulae.
\end{abstract}

\section{RESUME}

On souligne la nécessité d'une description meilleure et plus systématique de la chétotaxie, ceci s'appliquant surtout à l'aspect et à la structure des setae, ainsi qu'au modèle de leur distribution. On passe en revue de manière chronologique les développements des recherches sur la chétotaxie.

Il est possible de reconnaître deux types fondamentaux d'appendices cuticulaires: les setae et les pseudochaetae. Les premières remplissent des fonctions sensorielles et mécaniques, tandis que les autres ont seulement une fonction mécanique. L'aesthétasque, ou récepteur chémo-sensoriel, représente un type spécial de seta. Tenant compte de l'aspect et de la structure des setae, la plupart de celles-ci peuvent être rangées dans les catégories suivantes: simples, plumeuses, denticulées et a aspect de chela.
On souligne l'importance des recherches sur le développement dans le but d'établir des homologies au niveau de la chétotaxie.

Des exemples de morphologie fonctionnelle des setae sont analysés, et on arrive à la conclusion que la morphologie fonctionnelle de la majeure partie de celles-ci peut être mieux comprise par étude de l'organe entier dont les setae sont seulement une partie constitutive. Une signification adaptive n'est pas le propre de to u tes les setae.

On propose un modèle descriptif de la chétotaxie des Ostracodes Cypridacés. Les diverses particularités des setae, ainsi que leur position sur les extrémités, sont codés par lettres et chiffres, avec utilisation de formules simples.

\section{INTRODUCTION}

The superfamily Cypridacea is one of the groups most rich in species of the Ostracoda which successfully inhabits the limnic environment. The ostracod carapace and the soft body are covered with diverse setae like hairs, claws and specialized chemosensorial organs.

The pattern of distribution of the setae on the organism is generally called chaetotaxy (Kenneth, 1976). In this paper we use this term in connection with the studies of two basic types of cuticular processes that cover the ostracod soft body: the setae and the pseudochaetae (see section "Basic morphology and nomenclature" for the definition of these structures). The present study deals with the morphology, the classification and the pattern of distribution of the specific types of cuticular processes mentioned above.

The investigation of ostracod chaetotaxy is useful among other things in order to accurately 
define the taxonomic position of the organism, to obtain information on the way of life of the animal and to get insight in the phylogenetic affinities with other ostracod taxa. Due to this large area of interest it is understandable that zoologists concentrated on the description of the chaetotaxy ever since the early stages of ostracod investigations.

After a review of the historical developments of chaetotaxy research in cypridacean ostracods, the need for better and more systematic descriptions is emphasized in the present paper. A basic nomenclature and a descriptive model is proposed and the arguments are exemplified with an analysis of developmental and functional morphology of some of the setae and pseudochaetae of Cypridacea.

\section{HISTORICAL DEVELOPMENTS}

The study of cypridacean chaetotaxy started at the beginning of the nineteenth century, incorporated in the general study of freshwater ostracods. The description of the setae during this period was not very well defined and mostly inaccurate, see e.g. the descriptions of Liljeborg (1853) or those of Vejdovský (1882). In order to document this statement, a plate of the "Dictionnaire des sciences naturelles" edited by Frédéric Cuvier in the years between 1804 and 1830, is reproduced here in fig. 1 . On this plate one can recognize representatives of the subfamilies Candoninae, Cypridinae and Notodromatinae of which the setae are only approximately figured.

It was during the end of the last century and the beginning of the present one that zoologists started to represent ostracod limbs in an accurate way. The most significant contributions are those of Müller (1900) and Sars (1925). During the last fifty years a wide range of aspects has been investigated in relation to the chaetotaxy of the Cypridacea: contributions on general morphology of setae using light and electronmicroscope techniques (Rome, 1947; Triebel, 1961; Danielopol, 1972, 1973; Andersson, 1975; etc.), on functional morphology (Cannon, 1926; Storch, 1926), on chaetotaxy classification for taxonomy (De Deckker, 1979; Maddocks, 1976, 1979) and for phylogenetic reconstruction (Danielopol, 1976, 1978).

\section{TOWARDS BETTER DESCRIPTIONS OF CHAETOTAXY}

Besides the positive achievements mentioned above, still very poor descriptions of ostracod setation are being published. Many papers of W. Klie suffer from this deficiency (e.g. Klie, 1941). Some authors figure indiscriminately bristles that are irrelevant, for instance Paulo (1969: 28, fig. 10) in his description of the chaetotaxy of the maxilla. This negative situation occurs mainly because there is not enough information about the functional and developmental characteristics of the setae of many ostracods. Neither are there enough data to recognize homologies and analogies between setae, nor are the differences between setae and pseudochaetae well understood.

The ostracodologists working on carapace morphology found it useful to standardize the terminology in order to improve the descriptive data (for different reviews see: Hartmann, 1966; Sylvester-Bradley \& Benson, 1971; Keyser, 1980).

Considering the chaetotaxy of the limbs, $\mathrm{Da}$ nielopol \& Cvetkov (1979) proposed a system of description of the setae using letters and numerals. A less developed system has been used by Shornikov (1980). The advantage of such a system consists in a more complete description of the setation of the limbs in an abridged form. It also allows the retrieval of data for computer storage and treatment because of the symbolized language used.

In the following a basic nomenclature for the setae of cypridacean limbs and a descriptive model for the chaetotaxy will be proposed. It will be demonstrated that understanding the development of the setae and their functional purpose (if any) is a prerequisite to improve the knowledge of the chaetotaxy of ostracods.

\section{BASIC MORPHOLOGY AND NOMENCLATURE}

The term seta comes from the latin seta which means bristle or hair; the greek equivalent is chaeta (Kenneth, 1976). A seta, as an organ, is a cuticular process, normally conical or tubular, in most of the cases articulated at a socket on the 


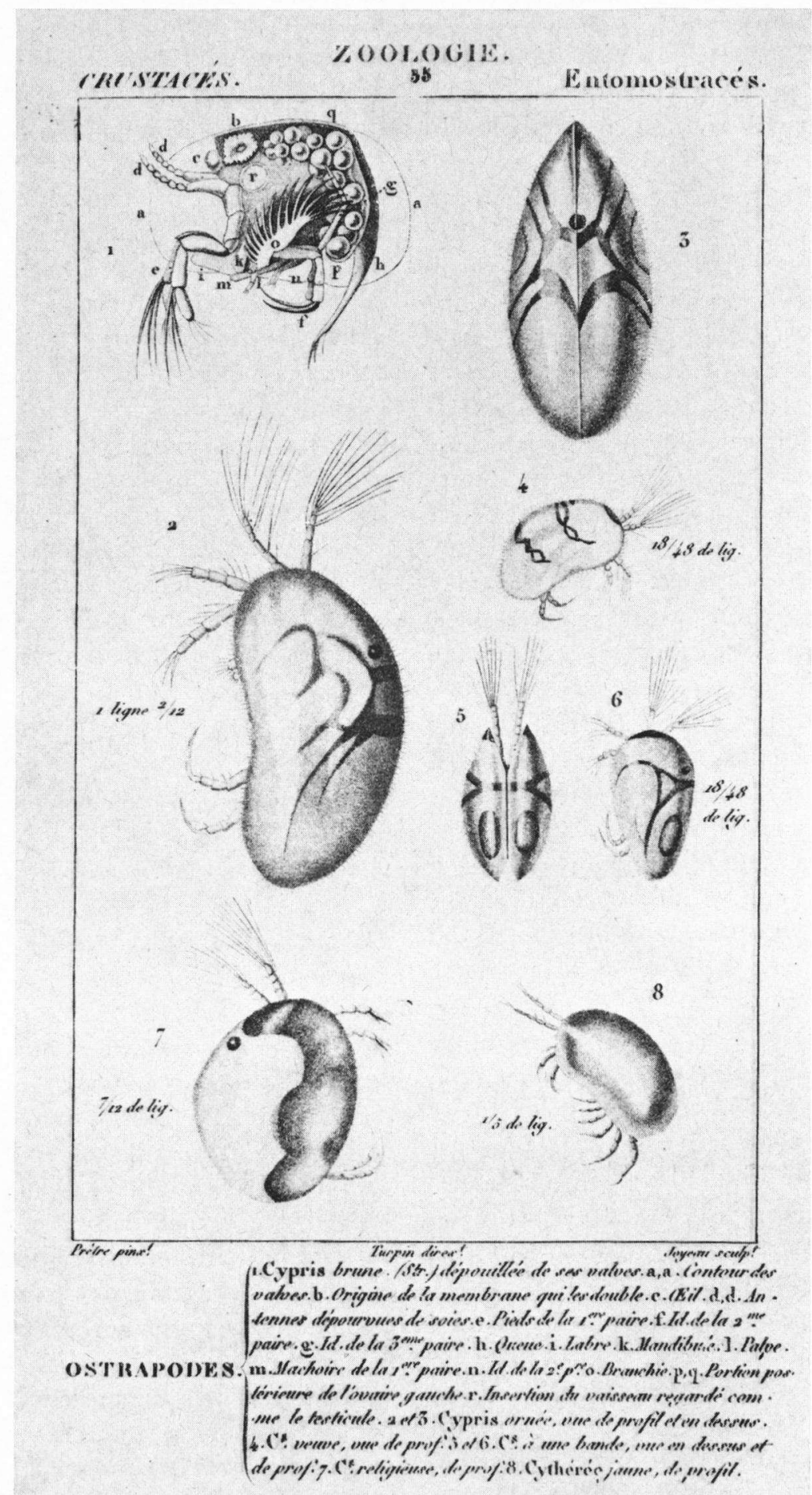

Fig. 1. Ostracods illustrated in "Dictionnaire des sciences naturelles" edited by Frédéric Cuvier; Desmarest was responsible for the text on ostracods (published in 1823, being a part of his article "Malacostracés") and for the plates on crustaceans in this work (published 1816-1830; plate 55 is reproduced here). The valve and carapace shape of ostracod no. 1 conform well with those of Candoninae, no. 3 with Cypridinae and no. 7 with Notodromatinae. The Cypridinae (no. 2) should have swimming setae on the second antenna, instead of the Candoninae (no. 1). The chaetotaxy of the first endopodal segment of the second antenna of ostracod no. 2 recalls some "giant" pseudochaetae, which are imaginary because European freshwater Cypridinae all have minute pseudochaetae. 
limb, having an inner lumen in which nervous cells terminate. The seta plays a sensory and mechanical role (Rome, 1947).

A seta, as defined above, is a morphological character which can not logically be subdivided further but can be expressed in a variety of forms like: thin hairs, feathered bristles, clawlike structures, etc. The various expressions of morphological characters are called character states (Crovello, 1970; Stevens, 1980). The setae generally have a proximal shaft separated from the distal one by an annulation (fig. 2A). The external morphology of the setae differs widely. Heavily sclerotized setae form clawlike or chelate setae (hardened, curved processes). In ostracods most of the setae are thin and flexible.

The setae can be ornamented with tiny setules, denticles or scales. Most of the ostracod setae basically look like those of other crustacean groups (for decapod data see: Thomas, 1970; Farmer, 1974; Drach \& Jacques, 1977). In the following description several terms are adopted from decapod literature (viz., simple setae, plumed setae, serrate, plumose, pappose, pseudochaeta).

When the distal shaft of the seta is smooth, it will be called simple seta. Most of the setae are covered with setules. When the setules are flexible and have a hairy appearance, the setae are said to be plumed setae (fig. $2 A)$. When the setules are spiky or toothlike they are called serrate setae (fig. 2G). The plumed setae can be divided into $\mathrm{pl} \mathrm{u}$ mose set a e when the setules are disposed on one or two rows along the distal shaft (fig. 2C), and pappose setae when the setules arise on all sides of the shaft (fig. 2D). The chelate setae can be smooth or serrate.

Some special setae can be easily recognized from their morphology and/or position. Danielopol (1970, 1972, 1978), Danielopol \& McKenzie (1977) and Danielopol \& Cvetkov (1979) used for such setae a symbolic system of letters and numerals. For instance some setae of the mandibular palp have been called seta $\alpha, \beta$ and $\gamma$ (Danielopol \& McKenzie, 1977).

A second major type of seta is the aesthetasc. This is a specialized seta with a chemosensorial receptor. The distal shaft of this type of seta is markedly developed (fig. 2E). The surface of the seta is in most cases largely increased (Danielopol, 1972) and the innervation is very complex (Andersson, 1975).

Another type of cuticular process is the p seud och a et a (figs. 2B, F). This is a tiny cuticular production having no basal articulation and no inner lumen; it is not innervated and has only a mechanical function. Rome (1947) described the fine structure of a pseudochaeta when delineating the morphology of the walking legs (see his plate $\mathrm{V}$ figs. 44-45). The main role of the pseudochaetae is to prevent adhesion of microparticles on the ostracod limbs (see for example Danielopol, 1978, fig. 25). Exceptionally, in the case of the terrestrial ostracods of the genus Mesocypris, some of the pseudochaetae play a protective role preventing the desiccation of the soft body (Danielopol \& Betsch, 1980).

\section{DEVELOPMENTAL ASPECTS}

One of the central problems in the study of chaetotaxy is the recognition of similarities between different setae due to inheritance from a common ancestor. Jardine (1969) suggested that one of the most effective criteria for identifying such homologies is the correspondence in relative position. In ostracods one of the problems is that in order to understand the relative position of the setae, it is necessary to obtain information on how these structures develop. In some cases the morphogenesis of the ostracod limbs happens within one juvenile stage, while in other cases it happens sequentially during several developmental stages (Van Morkhoven, 1962). An example of the first case is the development of the pincer complex (cleaning organ) of the second thoracic leg in Cypridacea. In Herpetocypris chevreuxi (G. O. Sars) this complex comes into being just before the moulting of the sixth juvenile instar (figs. 3A, C, D). However, the setation of the antennula and antenna develops sequentially during several moult stages. From one stage to another the setae can change their morphology and sometimes their position on the limb (Danielopol, 1970, 1978, 1982).

The following is an example of the way in 


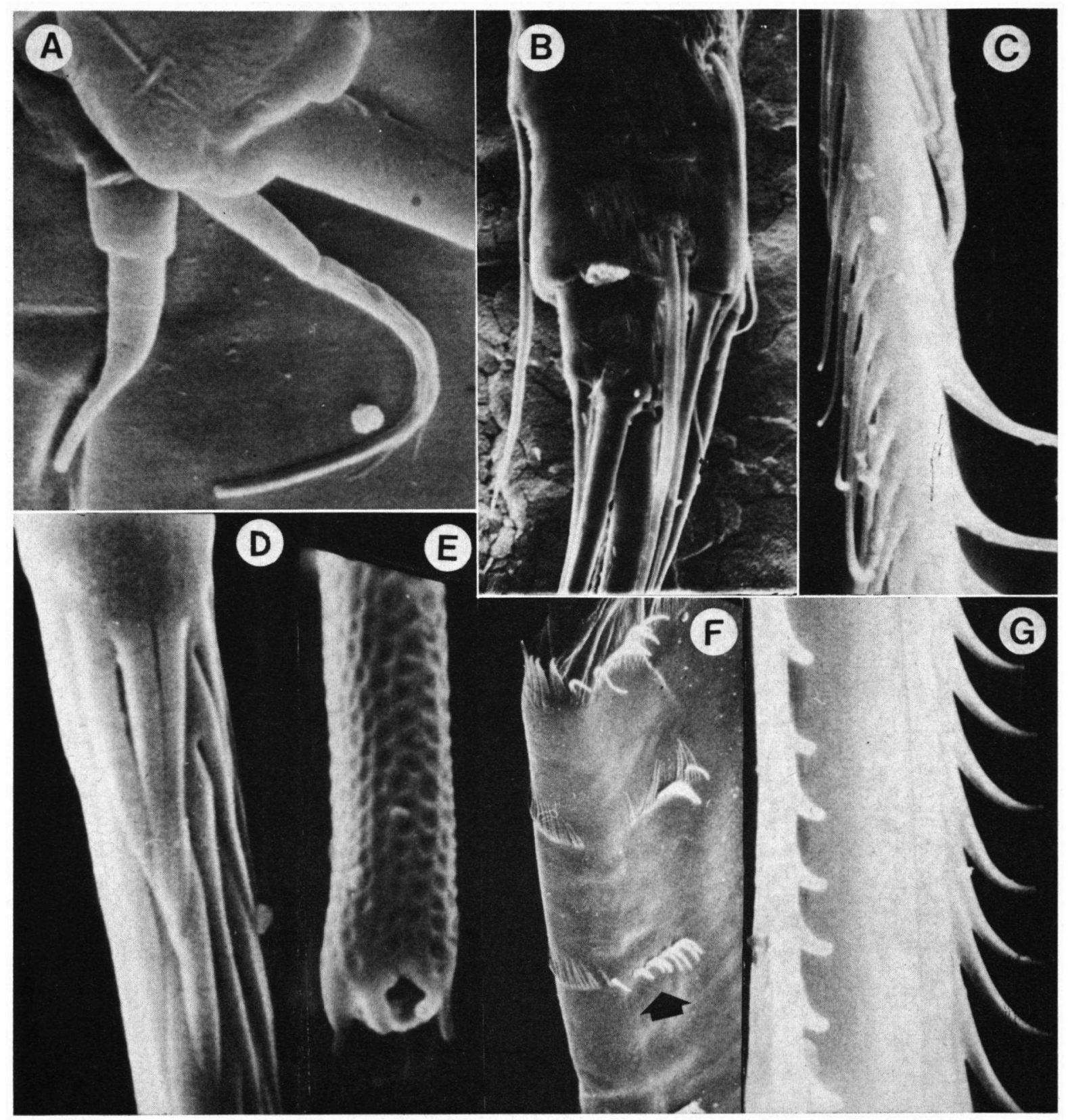

Fig. 2. Details of the chaetotaxy of the second antenna in Cypridacea: A, D, F, G, Pseudocandona delamarei Danielopol (Sauve, Gard, France); B, Ilyocypris bradyi (Sars) (Lake Caldarusani, Romania); C, Cryptocandona sp. (Volp, Ariège, France); E, Mixtacandona sp. (Cuhea, Maramures, Romania); (A, D, G, male; B, C, E, F, female). A, exopodite with annulated setae, one plumed ( $X$ 5655); B, endopodite with distal $t$ and $z$ setae $(X 870)$; $C$, plumose seta of protopodite $(X 10440) ; D$, pappose seta of first endopodite $(X 20880)$; E, aesthetasc $Y$ ( $X 19140)$; F, pseudochaeta of first endopodal segment $(X 4872) ; G$, claw $G_{M}$, note the strong serration of this seta $(X 9570)$. 


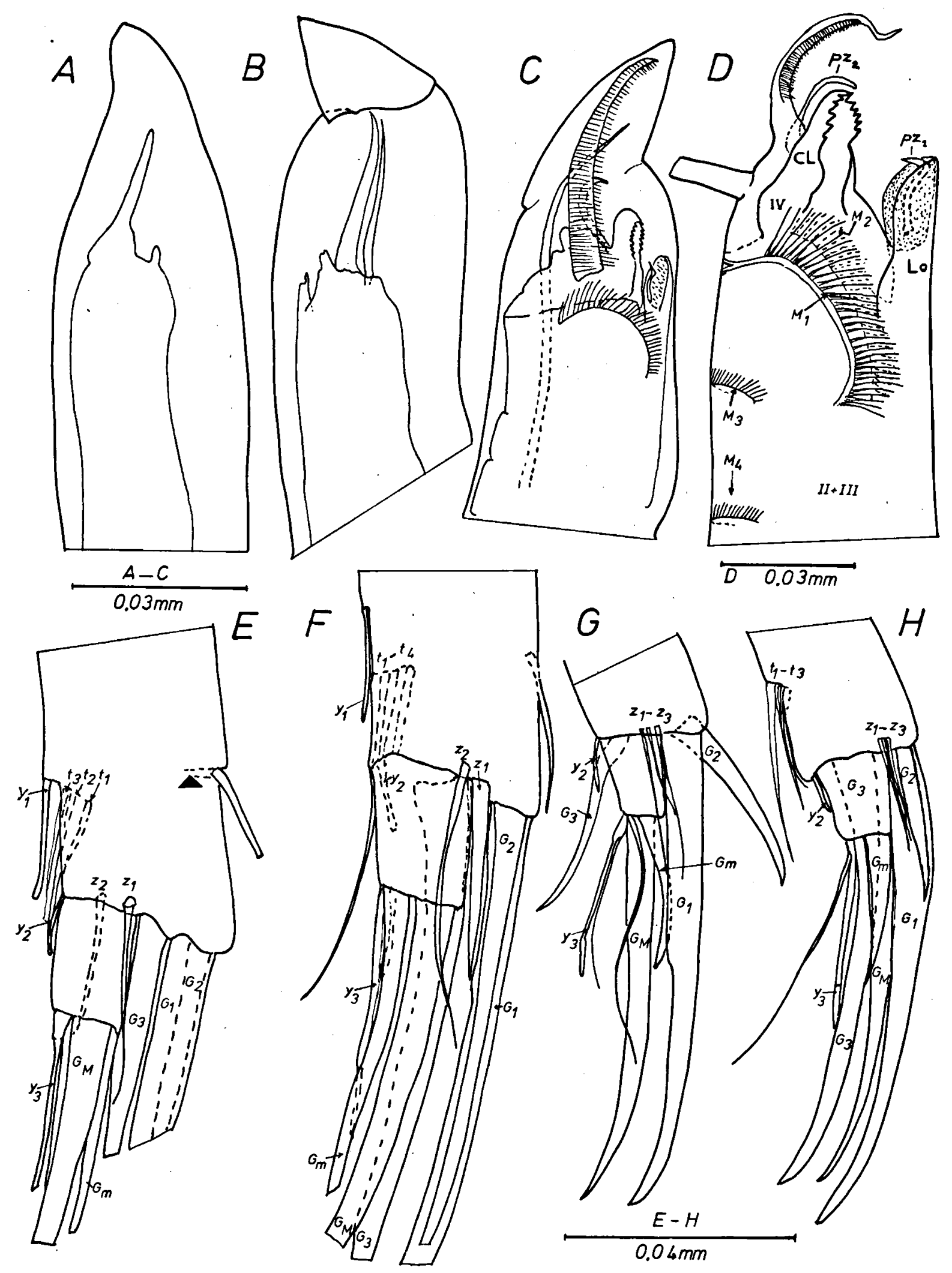

Fig. 3. A-D, Development of the second thoracic leg, the pincer organ and the chaetotaxy of Herpetocypris chevreuxi (Sars) (isle of Majorca, Spain), female: A-C, sixth instar, D, adult; E-H, Details of the endopodal chaetotaxy of the second antenna: E-F, Pseudocandona zschokkei (Wolf) (Rhône valley, Lyon area, France), G-H, Pseudocandona inaequivalvis baikalensis Bronstein (Baikal Lake); (E, G, male; F, H, female). The black triangle indicates the undeveloped articulation between the second and third endopodal segments. 
which a developmental study of the chaetotaxy can help to solve the problem of phylogenetic affinities between two geographically isolated ostracod species: Pseudocandona zschokkei (Wolf), a groundwater ostracod from western Europe, and Pseudocandona inaequivalvis baikalensis Bronstein from Lake Baikal.

Before discussing this problem it should be remembered that most of the Candoninae have sexually dimorphic second antennae. The maie antenna has a four-segmented endopodite and two strongly developed $t$ setae, while the female antenna has a three-segmented endopodite and undifferentiated $t$ setae (e.g. in Pseudocandona serbani Danielopol, 1982, see figs. 4C, D).

The discovery of Candona insculpta Müller, without these dimorphic characters (both sexes have a three-segmented endopodite and undifferentiated $t$ setae) prompted Kaufmann (1900) to erect a new genus, Pseudocandona. Most of the dimorphic Candoninae remained grouped during Kaufmann's time in the genera Candona, Cryptocandona and Candonopsis. Other Pseudocandona species sensu Kaufmann have been discovered in Europe [Ps. zschokkei (Wolf, 1919)] and in Asia [several species in Lake Baikal (Bronstein, 1939, 1947)]. This last author, considering the morphological similarities of the second antenna of the European and Baikal species, concludes that Ps. zschokkei is related to the Baikal Candoninae. According to Bronstein (1939) the origin of these species should be found in an Old Tertiary, widely distributed Candoninae fauna, that was found in the whole Palaearctis. A reexamination of the species allowed Colin \& Danielopol (in litt.) to demonstrate that the two groups are not phylogenetically related and that the genus Pseudocandona as defined by Kaufmann is a polyphyletic taxon. A redefinition of this genus has been published by Danielopol (1978).

At a close examination of Ps. zschokkei (figs. $3 \mathrm{E}, \mathrm{F}$ ), it can be seen that the second antenna is sexually dimorphic. The female has four $t$ setae and two $\mathrm{z}$ setae located on the lateral side, while the male has only three $t$ setae and two $z$ setae, one of which is located on the medial side of the endopodite. Ps. inaequivalvis baikalensis (figs. $3 G, H)$ has no dimorphism with respect to the $t$ and $z$ setae, but it presents a dimorphism with respect to the claw $\mathrm{G}_{3}$.

Considering the common morphological type of the Candoninae, for example the second antenna in Ps. serbani (fig. 4), it can be noticed that the $t$ and $z$ setae develop sequentially, starting at the sixth instar. After each moult a new seta comes into being and in the adult male two setae $\left(t_{2}\right.$ and $\left.t_{3}\right)$ change their morphology drastically and one $z$ seta changes its position from the lateral to the medial side.

Taking the development of $P_{s}$. serbani as a "normal" or standard type, it can be inferred that the antennae of Ps. zscbokkei and Ps. inaequivalvis baikalensis show a paedomorphic aspect. The $t$ setae of the adult male P.r. zschokkei correspond to the eighth instar chaetotaxy of Ps. serbani and the $z$ setae in $P_{s}$. zscbokkei have a pattern typical of the seventh instar of "normal" Candoninae. In the case of Ps. inaequivalvis baikalensis the development of the chaetotaxy stopped shortly before sexual differentiation in the last phase of the eighth instar.

These data, added to other morphological differences in the hemipenis and Zenker organ structures, convinced Colin \& Danielopol (in litt.) that the European groundwater Candoninae (e.g.: Ps. zschokkei) are not phylogenetically closely related to the Baikal Candoninae. With this example we stress the necessity of studying thoroughly the developmental aspects of the chaetotaxy of Cypridacea.

\section{FUNCTIONAL MORPHOLOGY}

A better description of the chaetotaxy in cypridacean ostracods creates the opportunity to question the purpose of such morphological structures or patterns. Functional morphology will help to identify analogies between setae and to distinguish between analogical and homological characters, important in phylogenetic research as it is possible to reconstruct evolutionary pathways of some cyprideacean groups in this manner (cf. Riedl, 1978).

In the sequel, several aspects of the adaptive problem of the chaetotaxy in two cypridacean 

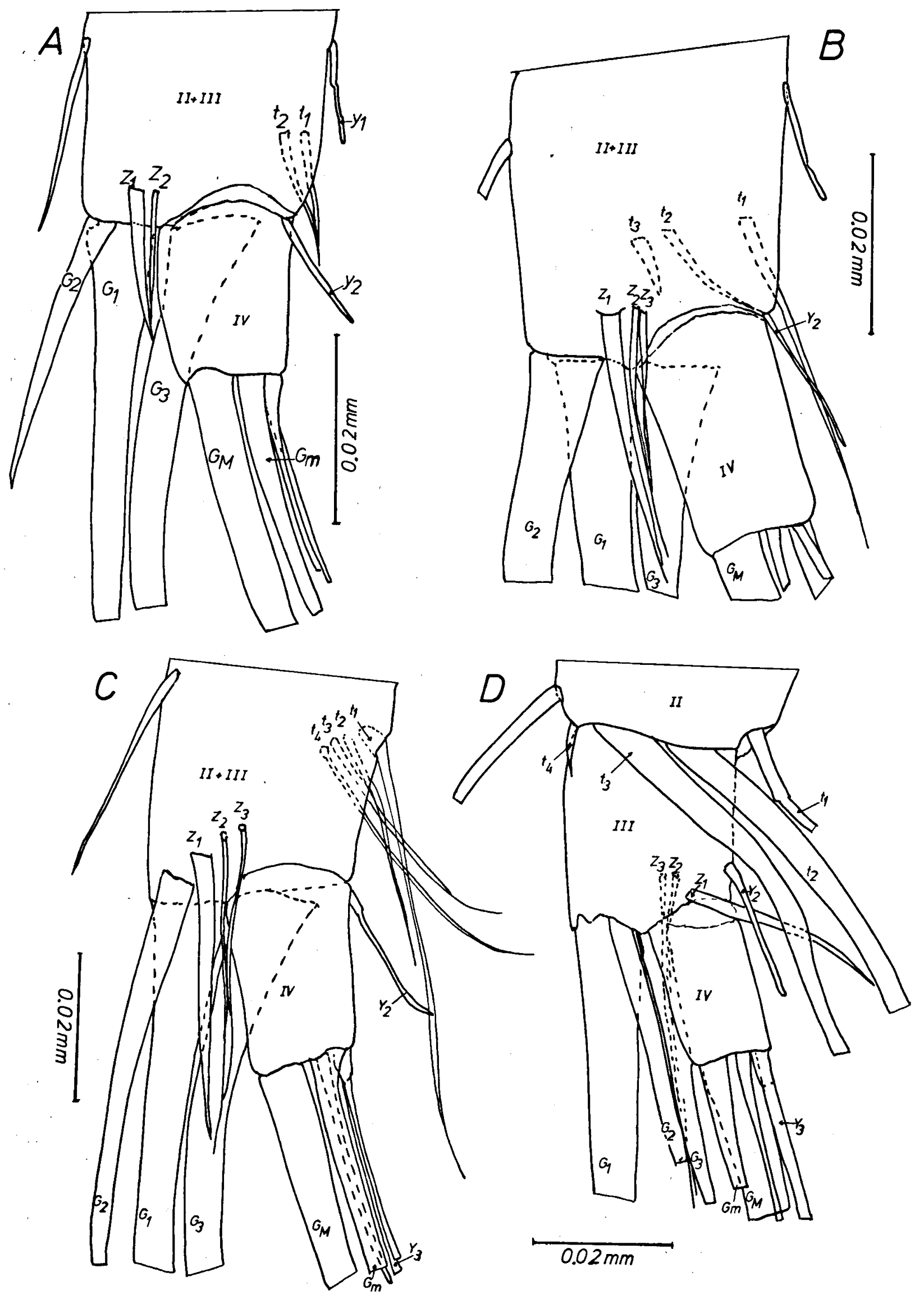

Fig. 4. Pseudocandona serbani Danielopol, 1982 (Jiblea, Vilcea, Romania), second antenna, details of the endopodal chaetotaxy: A, seventh instar; $B$, eighth instar; $C-D$, adults (C, female, $D$, male). 
ostracods, Notodromas persica Gurney and Herpetocypris chevreuxi (Sars) are discussed.

A definition of adaptation is provided by Lewontin (1978): "Adaptation is the process of evolutionary change by which the organism provides a better and better 'solution' to the 'problem' and the end result is the state of being adapted". According to Williams (1966), Lewontin (1978) and Jaksic (1981), one way to evaluate the adaptive value of morphological structures is to view them through engineering analyses.

\section{The setae as isolated organs}

The right endopodite of the maxilla in the male of Notodromas persica has on its distal segment a long seta, with one row of setules (figs. $5 \mathrm{~A}, \mathrm{C}$ ). Its function is tactile, the male touches the female during mating. Similar cases have been noticed in representatives of the Candoninae (Danielopol, 1980). In the Candoninae the endopodite of the male maxilla touches the female in the early phases of mating, in order to stimulate the reaction of "sexual acceptance".

The proximal endopodite segments of the male maxillae in $N$. persica bear two minute setae (figs. $5 A, D, F)$. The seta on the right maxilla is pappose, while that on the left one is smooth. 'The function of these minute setae remains uncertain when they are regarded as isolated organs. It is not certain that they play a positive tactile role during mating activity. In the Candoninae, where the distal setae are reduced to hyaline smooth tips, the proximal endopodal setae are long and well sclerified, for instance the maxillary palps in the male of Candona dancaui Danielopol (Danielopol, 1978, figs. 8E, F). Both the proximal and the distal setae of these palps play a tactile role in the Candoninae.

\section{Chaetotaxy as part of an integrated structural complex}

Gould \& Lewontin (1979) and Gould (1980) showed that the structure and/or function of many morphological characters can be better understood within the framework of an integrated structural complex. When the male maxillar endopodites of Notodromas persica (figs. 5 A-G) are examined as a whole, it is clear that their morphology is complex. The right distal endopodite has, besides the distal seta, on its surface two sclerified lamellae (fig. 5B) which can also play a tactile role. The left endopodite has on the proximal segment two large hooks and on the distal segment an irregular sclerified strip (fig. $5 \mathrm{~F}$ ). Note that the left endopodite has no distal seta like most of the cypridacean ostracods. Considering the global evolution of the male maxillar endopodites in order to evaluate the tactile function, it is noticeable that some of the morphological structures, like the distal seta and the sclerified lamellae of the right palp, are well developed, while other structures disappeared completely (the left distal seta) and some remain in the form of vestigial elements (the proximal minute setae).

In the case of Notodromas persica the specific tactile information is transmitted to the female through the highly specialized structures mentioned above. A related species, N. monacha (O. F. Müller), has developed a completely different set of morphological characters in order to transmit sensorial information (Petkovski, 1959). Referring back to the minute setae of the proximal endopodal segment in the male of $N$. persica, within the framework of an integrated tactile structure it can be inferred that their functional importance is reduced. The differences between the right pappose minute seta and the left smooth one may be due to the different genetic constraints under which those two structures developed.

A second example will be provided regarding the chaetotaxy of the "pincer complex" (cleaning organ) of the second thoracic leg of Herpetocypris chevreuxi (fig. 3D). In this species the pseudochaetal formations $M_{1}$ and $M_{2}$, which relate directly to the pincer complex, are better developed (larger and the pseudochaetae are longer) than the pseudochaetal series $\mathbf{M}_{3}$ and $\mathbf{M}_{4}$, which are located far from the pincer. Several other adaptations are present in order to increase the cleaning function of this leg, viz., a strongly bent and serrate distal seta, the denticulate beak-shaped distal endopodal segment and a concave lobe, finely haired, that developed from the subterminal endopodal segment. Two endopodal setae, $\mathrm{pz}_{1}$ and $\mathrm{pz}$, are very reduced and obviously play no role in the mechanical activities of the pincer. 


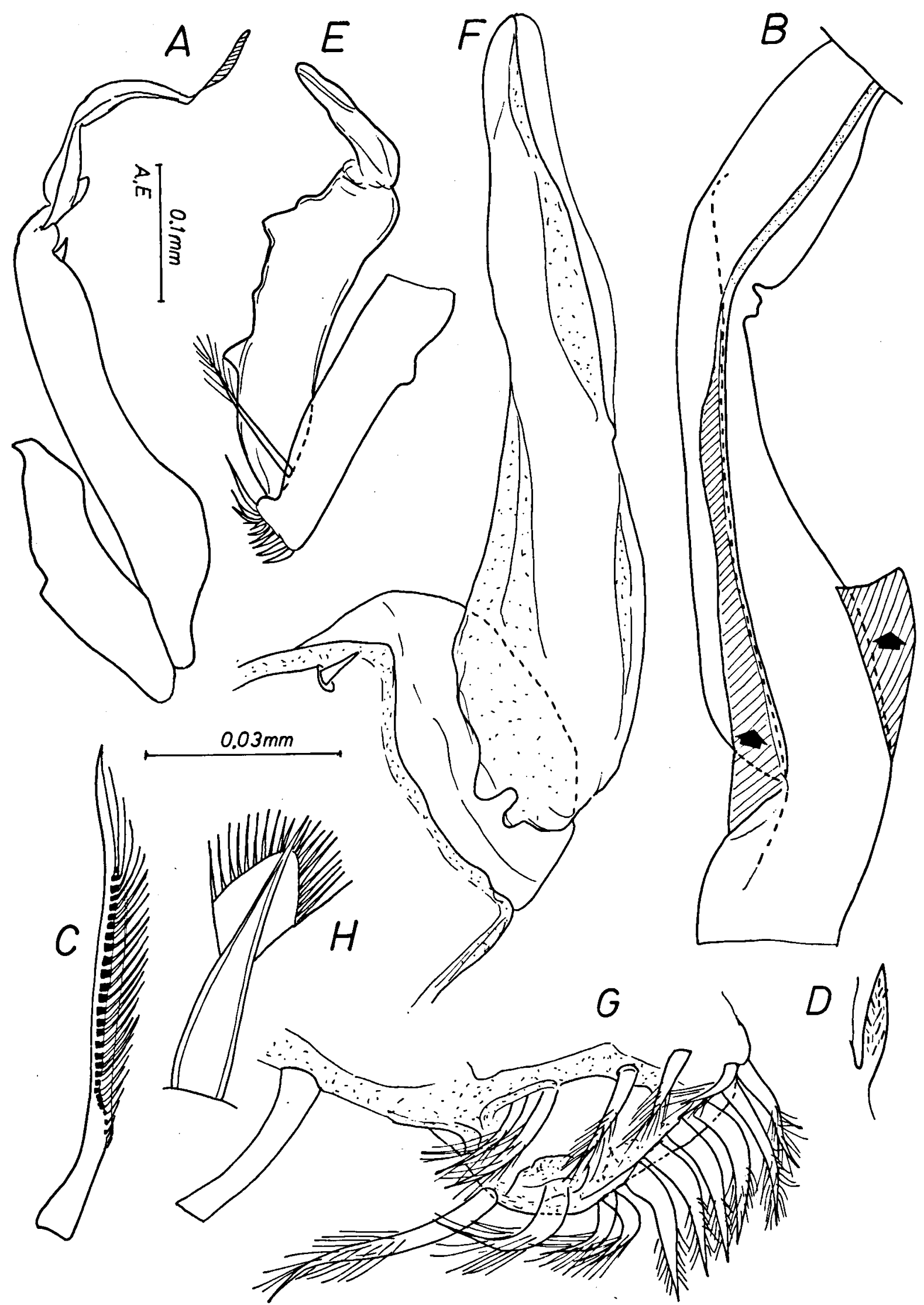

Fig. 5. Notodromas persica Gurney (Lake Caldarusani, Romania), male: A-D, right maxilla; E-G, left maxilla: B, distal endopodal segment, arrows indicate the sclerified lamellae; $C$, distal endopodal seta; $D$, minute seta of the first endopodal segment; F, distal part of the left endopodite, note the minute simple seta of the first segment; G, distal chaetotaxy of the maxillar protopodite and the unique exopodal seta; $H$, maxillule, distal seta of the first endite. 


\section{Chaetotaxy and basic functional adaptations}

In some cases the pattern of setal distribution on the ostracod limbs is the result of the adaptation of the animal to special environmental situations. A case in point is the chaetotaxy of the maxillar protopodite of Notodromas species. The Notodromatinae are neustonic animals feeding on the fine particles that occur on the surface of the water, while most of the cypridaceans feed on bottom substrates. Besides the adaptation of the carapace to enable this surface feeding activity (see morphological details in Müller, 1900) there are also diverse morphological changes in the structure of the second antenna, the mandibular palp, the maxillular endites and the maxillar protopodites. The last mentioned have an unusual distribution pattern of the distal setae, i.e. they are disposed in two rows, each placed on a sclerified frame (fig. 5G) and they are pappose and short. In most of the cypridacean ostracods the setae of the maxillar protopodite are inserted in one row, on the unsclerified distal margin and they are also pappose but longer than in Notodromas. If these adaptations are accepted to have a function in the gathering of fine food particles from the surface and bringing them to the mouth, then these adaptations constitute a good engineering solution in order to increase the brushing efficiency of the limbs and to gather widely dispersed particles distributed as a thin layer on the water surface. It is more difficult to explain the peculiar shape of the distal setae on the maxillular endite (fig. $5 \mathrm{H}$ ).

\section{Not all setae have an adaptive function}

It should be stressed that even well-developed setae may apparently have lost their former main function. For instance the chaetotaxy of the maxillar exopodite in many cypridacean ostracods is considered to play a significant role in moving the water within the carapace space. In the case of Notodromas persica the maxillar exopodite is presented as a unique seta, inserted directly on the protopodite (fig. 5E). Most cypridacean bottom dwellers have six setae inserted on a small exopodal segment (fig. 7C). Obviously the unique seta of $N$. persica can not play a significant role in the water movement through the carapace. Its only adaptive function could be a sensorial one; however, there is no intuitive or empirical evidence for this function.

From the data in this chapter it is concluded that the functional morphology of the chaetotaxy can be better understood if the whole organ is studied, because the setae are only a component of it.

\section{THE DESCRIPTIVE MODEL}

This descriptive model treats the chaetotaxy of the different limbs. The model uses abbreviations for the different segments of the limbs, together with the position, the number, the type, length and eventually setulation or barbulation of the setae on the segments. The list of abbreviations and symbols used in this system is provided in table I.

The segments. - All segments are represented by letters and roman numerals. The letters used are abbreviations of the names of the segments, while the segment number is indicated by a roman numeral. Most encountered are: endopodite (E), exopodite (Exo) and protopodite $(\mathrm{Pr})$. The other abbreviations are provided in table I.

The length of the segments is measured from articulation to articulation. If this is not possible because the articulations are not clearly demarcated, the length is measured by drawing lines at both ends of the segments and measuring the distance between the centres of these lines, as in fig. 7D. The position of the setae. - The setae can have different positions on the limbs, also depending on the orientation of the limb itself on the animal. So when the limb lies in the same plain as the body axis and the carapace hinge, the orientation can be anterior $(A)$, posterior $(P)$, lateral (L) or distal (D). When the limb is more or less at right angles to the main body we use interior (In) and exterior (Ex), instead of anterior and posterior.

The length of the seta e. - The length of the setae will be related to the length of a segment of the respective limb, in a way as explained in table II. For example, if a seta of 
TABLE I

Symbols used in the chaetotaxy system.

\begin{tabular}{llllll}
\hline General & & & & \\
\hline A & anterior & I to VII & 1st to 7th segment & Mxu & maxillula \\
A 1 & antennule & In & interior & Mxup & maxillular palp \\
A 2 & antenna 2 & L & lateral & P & posterior \\
cs & chelate seta & $l$ & long & pa & pappose \\
D & distal & M & medial & Pr & protopodite \\
E & endopodite & m & medium & pl & plumed \\
Ex & exterior & Mastic & masticatory process & pu & plumose \\
Exo & exopodite & Max & maxilla & s & small \\
Fu & furca & Md & mandible & ser & serrate \\
G & claw & Mdp & mandibular palp & T 1 (2) & thoracopod 1 (2) \\
\hline
\end{tabular}

Special setae, aesthetascs, etc.

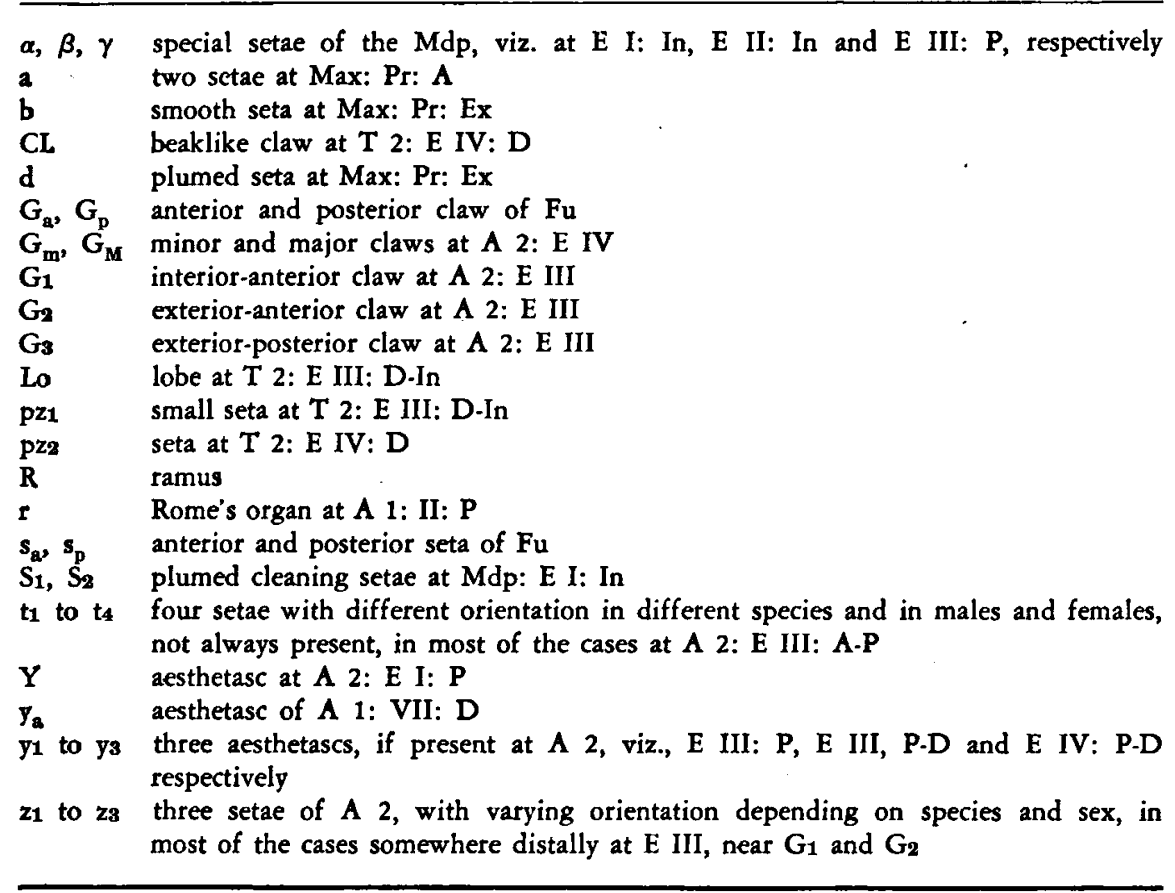

the antennule (A 1 ) is shorter than or as long as the third endopodal segment (E III), it is called small $(s)$. When it is longer than once, but shorter than or as long as twice the third endopodal segment, it is called medium $(m)$. When it is longer than twice the third endopodal segment it is called long $(l)$. This is done for each seta, comparing it with the corresponding segment of its limb as shown in table II.

Types of setae. - As mentioned in the preceding part of this paper there are different types of setae. Setae with flexible setules and a hairy appearance are called plumed $(\mathrm{pl})$, and if possible plumose $(\mathrm{pu})$ when the setules are disposed in two rows along the distal shaft, or pappose ( $\mathrm{pa}$ ) when the setules arise on all sides of the shaft (figs. 2A, C, D).

Setae with spiny or toothlike ornamentation will be called serrate (ser). Chelate setae will be called as such (cs); in the special case that they have the form of a claw they will be called claw (G) (after the French "griffe"). This last type of seta can be smooth or serrate with one (1ser) or two rows of spikes (2ser). 
TABLE II

The evaluation of the length of the setae as compared with their corresponding limbs.

\begin{tabular}{|c|c|c|c|c|}
\hline \multirow{2}{*}{$\begin{array}{l}\text { Abbreviation } \\
\text { of limb }\end{array}$} & \multirow{2}{*}{$\begin{array}{l}\text { Segment used } \\
\text { as reference }\end{array}$} & \multicolumn{3}{|c|}{ Relative length of setae (se) } \\
\hline & & Small $(s)$ & Medium $(m)$ & Large $(l)$ \\
\hline A 1 & E III & $\leqslant 1$ & $1<$ se $\leqslant 2$ & $>2$ \\
\hline A 2 & E I & $\leqslant 1 / 2$ & $1 / 2<$ se $\leqslant 1$ & $>1$ \\
\hline Mdp & E III & $\leqslant 1$ & $1<\mathrm{se} \leqslant 2$ & $>2$ \\
\hline $\mathrm{Mxu}$ & Mxup II & $\leqslant 2$ & $2<$ se $\leqslant 3$ & $>3$ \\
\hline $\operatorname{Max}$ & $\begin{array}{l}\text { Lateral } \\
\text { margin } \\
\text { protopodite }\end{array}$ & $\leqslant 1$ & $1<$ se $\leqslant 2$ & $>2$ \\
\hline T 1 & E II & $\leqslant 1$ & $1<\mathrm{se} \leqslant 2$ & $>2$ \\
\hline T 2 & E I & $\leqslant 1 / 2$ & $1 / 2<s e \leqslant 1$ & $>1$ \\
\hline
\end{tabular}

Some special setae which can be recognized from their morphology and/or position are discriminated by a symbolic system of letters and numerals (Danielopol, 1970, 1972, 1978; Danielopol \& McKenzie, 1977; Danielopol \& Cvetkov, 1979). The aesthetascs (specialized setae with a chemosensorial receptor) also have names represented by letters and numerals. Part of these symbol systems will be adapted here, as will be mentioned at the description of the different limbs.

The system. - First the abbreviation of the name of the limb is provided followed by the abbreviation of the name and number of the respective segment and the description of the setation of this segment. For example for antenna two: A 2: Pr: .../Exo: .../E I .../E II ...etc.

The name of the segment is followed by a position where setae are present, which position is followed again by the number and length of the setae at this position and so on for the other positions if more setae are present. For example: A 1:.../E IV: A-2l, P-1s-1m/...etc.

Special setae will also be named after the length is given, and aesthetascs will only be named. For example: A 2: .../E (II + III): (\%) $\mathrm{D}-\mathrm{y}_{2}-2 l$ $\left(\mathrm{z}_{1}, \mathrm{z}_{2}\right)-1 m\left(\mathrm{z}_{3}\right)-3 m\left(\mathrm{G}_{1}, \mathrm{G}_{2}, \mathrm{G}_{3}: 2\right.$ ser $)$, P- ...etc. (fig. 6C).

As a complete example we will provide the chaetotaxy of the antennule of a male Heterocypris margaritae Margalef (cf. fig. 6A): A 1: I: A-1s, P-2l(pl)/ II: A-1s/ III: A-1s, P-1s/ IV:
A- $2 l, \mathrm{P}-1 s-1 m / \mathrm{V}: \mathrm{A}-2 l, \mathrm{P}-2 l / \mathrm{VI}: \mathrm{A}-1 s-2 l, \mathrm{P}-2 l /$ VII: D- $\mathrm{y}_{\mathrm{a}} \cdot 1 m-2 l$.

The paper of Broodbakker (1982) in this same issue of "Bijdragen tot de Dierkunde" will serve as a good example of the use of this system.

\section{DESCRIPTION OF THE LIMBS}

Antennule (A 1). - At the posterior border of the second segment there is a sensory organ which is called "Rome's organ" (r). This organ can have various forms or it may be absent. In Heterocypris margaritae it is almost flush with the segment and not easily recognizable (fig. 6A). The only other organ of this limb with a special name is the antennular aesthetasc $y_{a}$, at the distal end of the seventh segment (according to Danielopol, 1978).

Antenna 2 (A 2). - This limb can have four aesthetascs. One relatively large one at the interior surface of the first endopodite, $Y$, which can be very large in hypogean species (Danielopol, 1978). The $y_{1}$, which is not present in $H$. margaritae, can be present in other species (fig. 4 ), at the interior side of the third endopodite near the second endopodite. At the interodistal side of this segment we also find $y_{2}$, while $y_{3}$ can be found at the interodistal side of the fourth endopodite (figs. 4, 6).

The three claws at the distal side of E III or E (II + III) are called $G_{1}, G_{2}$ and $G_{3}$ and the 


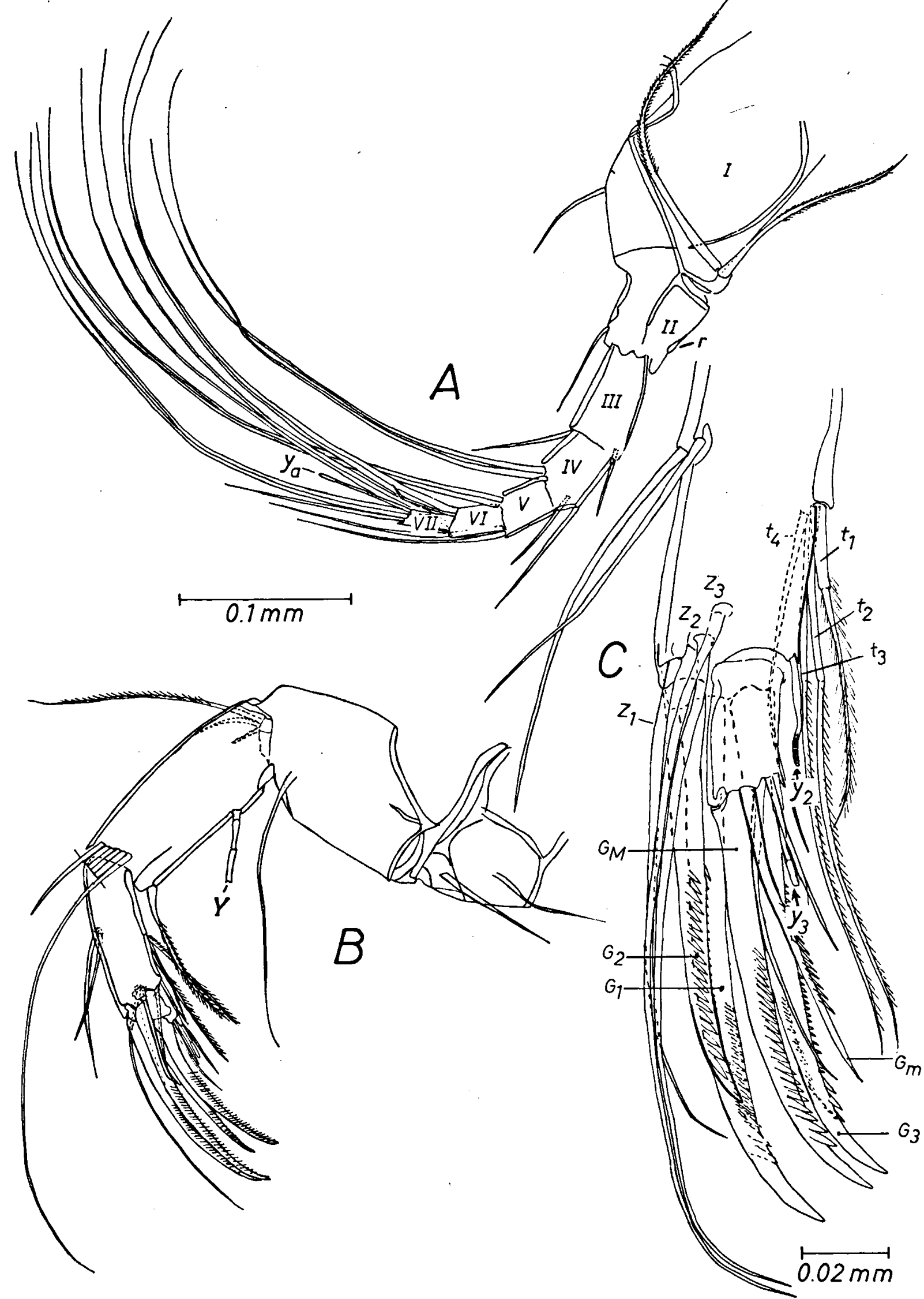

Fig. 6. Heterocjpris margaritae Margalef (Bonaire, Caribbean): $\mathbf{A}$, antennule (A 1); $B$, second antenna (A 2); C, detail of second antenna; (A-B, male; $C$, female). 
two claws of E IV are called $G_{M}$ (major) and $G_{m}$ (minor), according to Danielopol (1972, 1973, 1978) (figs. 4, 6). At the interior and/or exterior side of E III or E (II + III) we also find two rows of setae, the $t$ and $z$ setae. These setae can be short or long, the orientation can be different in different species and even between male and female of the same species. Sometimes not all of these setae are present. The maximum is three $z$ setae and four $t$ setae like in the female of $H$. margaritae (fig. 6C). Some of the variability in the orientation and shape of these setae is shown in fig. 4.

Mandibular palp (Mdp). - There are three setae on the palp that are clearly different from the rest, the $\alpha, \beta$ and $\gamma$ setae, at the interodistal borders of the segments I and II, and at the exterodistal border of segment III, respectively, as shown in fig. $7 \mathrm{~A}$. Furthermore there are two plumed setae, probably with a cleaning function, at the interior border of the first segment. They are called $S_{1}$ and $S_{2}$. The names for other setae as used in Danielopol (1978) will not be used in this paper.

M a xillu l a. - The maxillula does not present any specially named setae.

Maxilla (Max). - There can be two small setae at the anterior margin of the protopodite, the setae a, one plumose seta near the masticatory process, the seta $\mathrm{d}$, and one seta posterior of $d$, the seta b (fig. 7C) (Danielopol \& McKenzie, 1977).

Th or a c o pod 1 ( T 1 ). - The first thoracic leg does not present any specially named setae. Thoracopod 2 (T 2). - The cleaning leg has several special structures and pseudochaetal formations as mentioned in the preceding part of this paper and shown in fig. 3D. The structure of the distal part of this leg can be best explained in writing and with a detailed illustration instead of a series of abbreviations, as in the rest of this leg.

Most Cypridinae present a pincer organ at the distal part of the leg. The pincer organ has developed from the end of the third and the fourth endopodal segments. The interodistal side of the third segment has developed into a hairy lobe (Lo), forming the lower half of the pincers, which also carries a small seta, $p z_{1}$. The fourth segment presents a beaklike claw (CL), which is serrate at the top, with behind it another small seta, $\mathrm{pz}_{2}$. On the end of the segment also a larger, curved, serrate seta is borne (fig. 3D).

The pincer organ is a specialized adaptation of the Cypridinae. It is weakly developed in the Notodromatinae and absent in the Candoninae. In the Pontocypridinae the structure is totally different, with two chelate setae (one of which is strongly serrate) and a detritus lobe. A detailed descripton of these and other types of distal parts of this leg can be found in Danielopol (1978). F u r c a (Fu). - The furca terminates with two claws, an anterior one $\left(G_{a}\right)$ and a posterior one $\left(G_{p}\right)$; it also bears two setae, one anterior $\left(s_{a}\right)$ and one posterior $\left(s_{p}\right)$ (fig. $7 F$ ). In this we adopt the nomenclature of Danielopol \& Betsch (1980).

\section{CONCLUSIONS}

Isaac Levi (1980) in his essay "The enterprise of knowledge", emphasizes that scientific communities modify their knowledge by three different processes: expansion, contraction and replacement. Thoughtful observations and better descriptions of the chaetotaxy of ostracod limbs will certainly expand our understanding of the biology and evolution of these animals. The usage of the model of chaetotaxy description proposed here will help to contract, but not to eliminate, the information which is not immediately of interest to the ostracod student. This contracted information can later be activated, if necessary, by its incorporation in comparative descriptive models. Finally, the obligation to improve the examination of the chaetotaxy will bring new insights and new concepts on various matters of ostracod research, which should replace our present state of knowledge.

\section{ACKNOWLEDGEMENTS}

The initial impetus for the preparation of this paper came from Dr. B. Scharf (Mainz), who asked D. L. Danielopol to provide a synthetic system of description for the cypridacean chaetotaxy.

One of us (D. L. Danielopol) communicated with Dr. W. Thomas (London) and Dr. F. Jacques (Banyuls) on various topics of crustacean chaetotaxy. He received financial support 


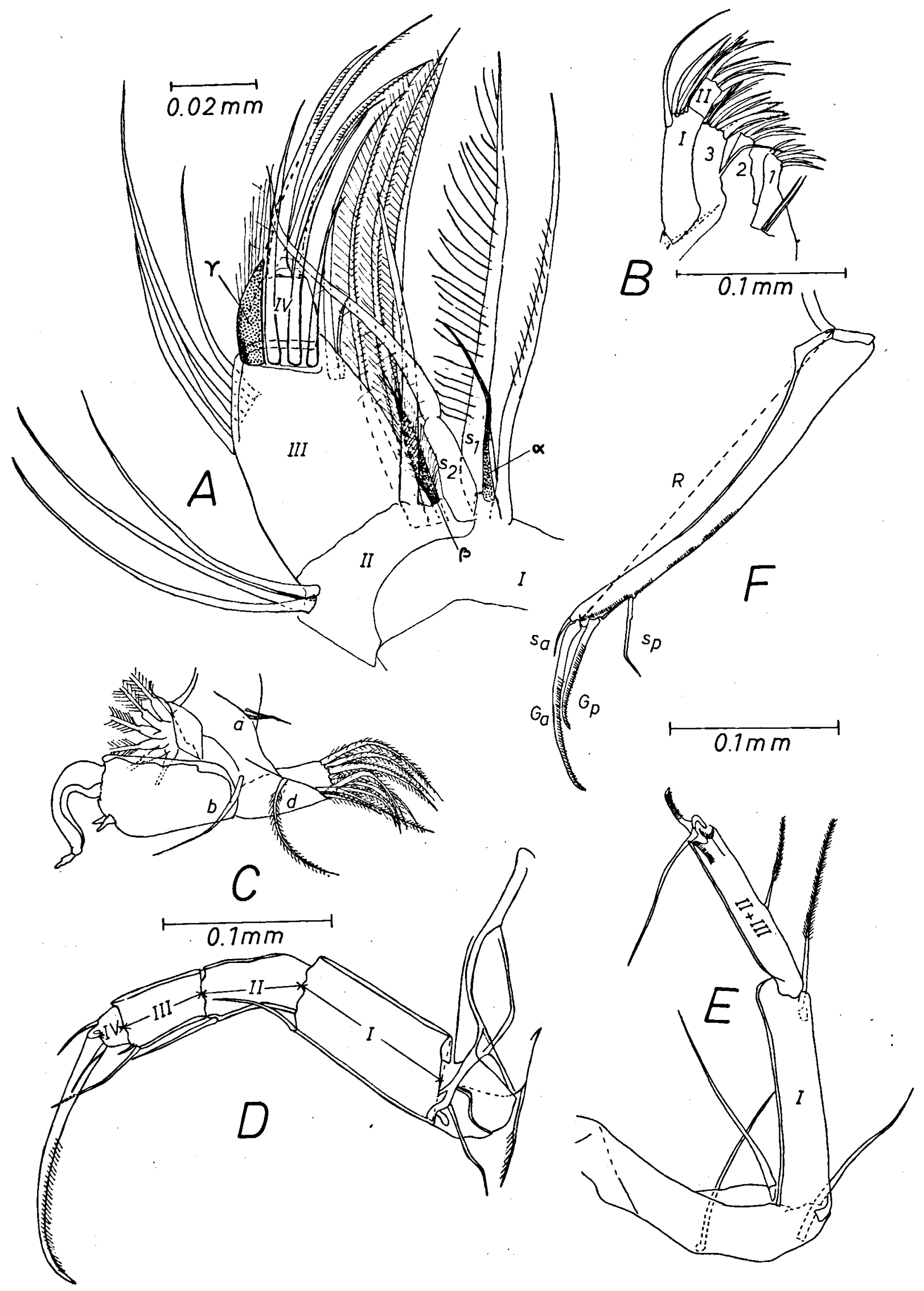

Fig. 7. Heterocypris margaritae Margalef (Bonaire, Caribbean), male: A, mandibular palp (Mdp); B, maxillula (Mxu); C, maxilla (Max); D, thoracopod one (T 1); E, thoracopod two (T 2); F, furca (Fu). 
for preparing this report from the "Verband der Wissenschaftlichen Gesellschaften Osterreichs" (Vienna). Prof. H. Löffler provided the Baikal ostracods figured here. Dr. T. Andrew (New University of Ulster) kindly read a first draft of this paper, which was further commented on by Prof. J. H. Stock (Amsterdam) and Prof. H. Löffler (Vienna).

The other author (N. W. Broodbakker) is financed by the Netherlands Foundation for the Advancement of Tropical Research (WOTRO), The Hague.

\section{REFERENCES}

Andersson, A., 1975. The ultrastructure of the presumed chemoreceptor aesthetasc " $Y$ " of a cypridid ostracod. Zoologica Scr., 4: 151-158.

BronsteIN, Z. S., 1939. On the origin of the Ostracoda fauna of the lake Baikal. Dokl. Akad. Nauk SSSR, (N.S.) 25: 333-337.

-, 1947. Faune de l'USSR, Crustacés, II (1). Ostracodes des eaux douces. Fauna SSSR, (N.S.) 31: 1-334 (Zoologicheskii Institut Akademii Nauk SSSR, Moskva \& Leningrad; in Russian, with title in French and summary in English).

Broodbakker, N. W., 1982. Amsterdam Expeditions to the West Indian Islands, Report 21. The genus Heterocypris (Crustacea, Ostracoda) in the West Indies. Part I. Taxonomic characters. Bijdr. Dierk., 52 (2): 207-227.

Cannon, H. G., 1926. On the feeding mechanism of a freshwater ostracod, Pionocypris vidua (O. F. Müller). J. Linn. Soc., (Zool.) 36 (244): 325-335, pl. 11.

Crovello, T. J., 1970. Analysis of character variation in ecology and systematics. A. Rev. Ecol. Syst., 1: 55-60.

Danielopol, D. L., 1970. Une nouvelle espèce du genre Darwinula des eaux souterraines de Roumanie et quelques remarques sur la morphologie des Darwinulidae (Ostracoda-Podocopida). Trav. Inst. Spéol. Emile Racovitza, 9: 135-149.

_-, 1972. Sur la structure des aesthetascs de l'antenne de quelques Cyprididae (Crustacea, Ostracoda, Podocopida). C. r. hebd. Séanc. Acad. Sci., Paris, (D) 271: 596-599.

—- 1973. Sur la morphologie des aesthetascs chez quelques Ostracodes hypogés de la sous-famille des Candoninae (Cyprididae, Podocopida). Annls. Spéléol., 28 (2): 233-246

, 1976. The superfamily Cypridacea: some remarks on the phylogenetical affinities between the main ostracod cypridacean groups. In: G. Hartmann ed., Proceedings of the 5 th international symposium on evolution of PostPaleozoic Ostracoda. Abh. Verh. naturw. Ver. Hamburg, (N.F.) 18/19 (Suppl.): 77-85, pls. 1-2.

- 1978 . Über Herkunft und Morphologie der süßwasserhypogäischen Candoninae (Crustacea, Ostracoda). Sber. öst. Akad. Wiss., math.-naturw. KI., (I) 187: 1-162.

- 1980. Sur la biologie de quelques Ostracodes Candoninae épigés et hypogés d'Europe. Bull. Mus. natn. Hist. nat. Paris, (4) (A, Zool.) 2 (2): 471-506.

- 1982. Nouvelles données sur les Candoninae (Ostracoda) hypogés de Roumanie et Yougoslavie. Bull. Mus. natn. Hist. nat. Paris, (4) (A, Zool.) 4 (in press).

DANielopol, D. L. \& J. M. BetsCh, 1980. Ostracodes terrestres de Madagascar: systématique, origine, adaptations. Revue Ecol. Biol. Sol, 17: 87-123.
Danielopol, D. L. \& E. Cvetkov, 1979. Trois nouvelles espèces du genre Mixtacandona (Ostracoda, Cyprididae, Candoninae). Hydrobiologia, 67: 249-266.

Danielopol, D. L. \& K. G. McKenzie, 1977. Psychrodromus gen. n. (Crustacea, Ostracoda), with redescription of the cypridid genera Prionocypris and Ilyodromus. Zoologica Scr., 6: 301-322.

DECKKER, P. DE, 1979. Evaluation of features distinctive in the taxonomy of the Cypridacea, above the generic level. In: N. Krstic ed., Taxonomy, biostratigraphy and distribution of ostracodes. Proceedings of the 7 th international symposium on ostracodes: 5-8 (Serbian Geological Society, Beograd).

Desmarest, A.-G., 1823. Ordre neuvième. Ostrapodes; Ostrapoda, Strauis. In: F. Cuvier ed., Dictionnaire des sciences naturelles, 28 (article Malacostracés): 408-415 (F. G. Levrault, Strasbourg/Paris \& Le Normant, Paris). , 1816-1830. Planches. Crustacés. In: F. Cuvier ed., Dictionnaire des sciences naturelles, Planches, 2 (Zool.): 21-27, pls. 1.58 (F. G. Levrault, Paris/Strasbourg).

Drach, P. \& F. Jacques, 1977. Système sétifère des Crustacés Décapodes. Principes d'une classification générale. C. r. hebd. Séanc. Acad. Sci., Paris, (D) 284: 1995-1998.

FARMER, A. S., 1974. The functional morphology of the mouthparts and pereiopods of Nephrops norvegicus (L.) (Decapoda: Nephropidae). J. nat. Hist., 8: 121-142.

GouLD, S. J., 1980. The evolutionary biology of constraint. Daedalus, Boston, Mass., 109: 39-52.

Gould, S. J. \& R. C. Lewontin, 1979. The spandrels of San Marco and the panglossian paradigm: a critique to the adaptionist programme. Proc. R. Soc., (B) 205: 581-598.

HartmanN, G., 1966. Ostracoda. Bronn's Kl. Ordn. Tierreichs, Bd. 5, Abt. 1, Buch 2, 4 (1): 1-121.

JAKsic, F. M., 1981. Recognition of morphological adaptations in animals: the hypothetico-deductive method. Bioscience, 31: 667-670.

JARDINE, N., 1969. The observational and theoretical components of homology: a study based on the morphology of the dermal skull roofs of rhipidistian fishes. Biol. J. Linn. Soc., 1: 327-361.

KENNETH, J. H., 1976. Henderson's dictionary of biological terms (8th ed.): 1-640 (Longman, London).

KeySER, D., 1980. Auftreten und Konstanz von Poren und Borsten auf der Schale von Podocopa (Ostracoda, Crustacea). Verh. naturw. Ver. Hamb., (N.F.) 23: 175-193.

KLIE, W., 1941. Süßwasserostracoden aus Südosteuropa. Zool. Anz., 133: 233-244.

LEVI, I., 1980. The enterprise of knowledge. An essay on knowledge, credal probability and chance: 1.462 (M.I.T. Press, Cambridge, Mass.).

Lewontin, R. C., 1978. Adaptation. Scient. Am., 239: 156-169.

LILJEBORG, W., 1853. Om de inom Skåne förekommande crustaceer af ordningarne Cladocera, Ostracoda och Copepoda: [i-ii], i-xv, 1-222, pls. I-XXVII (Thesis, Univ. Lund; Berlingska Boktryckeriet, Lund).

MADDOCKs, R. F., 1976. Quest for the ancestral podocopid: numerical cladistic analysis of ostracode appendages, a preliminary report. In: G. Hartmann ed., Proceedings of the 5th international symposium on evolution of PostPaleozoic Ostracoda. Abh. Verh. naturw. Ver. Hamburg, (N.F.) 18/19 (Suppl.): 39-54. 
Morkhoven, F. P. C. M. van, 1962. Post Paleozoic Ostracoda: Their morphology, taxonomy and economic use, 1: 1-204 (Elsevier, Amsterdam).

MülleR, G. W., 1900. Deutschlands Süßwasser-Ostracoden. Zoologica, 30: 1-112.

Paulo, L. F., 1969. Contribution à l'étude des Ostracodes du Portugal. Publçōes Inst. Zool. Dr. Augusto Nobre, 108: 1.39 .

Petkovski, T. K., 1959. Süsswasserostracoden aus Jugoslavien, 6. Acta Mus. maced. Sci. nat., 6: 53-75.

RIEDL, R., 1978. Order in living organisms: 1.313 (J. Wiley \& Sons, Chichester).

Rome, D. R., 1947. Herpetocypris reptans (Ostracode). Etude morphologique et histologique, I. Morphologie externe du système nerveux. Cellule, 51: 1-147, pls. I-XV.

SARS, G. O., 1925 (1922-1928). An account of the Crustacea of Norway, 9. Ostracoda (3-10): 33-176.

Shornikov, E. I., 1980. A review of the genus Zabythocypris (Ostracoda, Bairdiacea). Zool. Zh., 59: 186-198 (in Russian; summary in English).
Stevens, P. F., 1980. Evolutionary polarity of character states. A. Rev. Ecol. Syst., 11: 333-358.

STORCH, O., 1926. Uber den Fangapparat eines Ostrakoden. Zool. Anz., 31: 80-85.

Sylvester-Bradley, P. C. \& R. H. Benson, 1971. Terminology for surface features in ornate ostracodes. Lethaia, 4: 249-286.

Thomas, W. J., 1970. The setae of Austropotamobius pallipes (Crustacea: Astacidae). J. Zool., Lond., 160: 91-142.

Triebel, E., 1961. Süßwasser-Ostracoden von den Karibischen Inseln, 1. Cypridini. Senckenberg. biol., 42: 51-74.

VEJDOVSKÝ, F., 1882. Thierische Organismen der Brunnenwässer von Prag: 1.66, [1-4], pls. I-VIII (printed for the author, Rivnač in comm., Prag).

Willinms, G. C., 1966. Adaptation and natural selection: 1.307 (Princeton Univ. Press, Princeton, N.J.).

Wolf, J. P., 1919. Die Ostracoden der Umgebung von Basel. Arch. Naturgesch., (A) 85: 1-100. 